\title{
Regulation of access to hospital beds in emergency care and the development of integrated health services
}

Mariana Konder ( $\nabla$ marianakonder@gmail.com)

Universidade do Estado do Rio de Janeiro Faculdade de Ciencias Medicas https://orcid.org/0000-0002-7787-4983

Gisele O'Dwyer

Escola Nacional de Saude Publica - Sergio Arouca

\section{Research article}

Keywords: Health Care Coordination and Monitoring, Health Services Accessibility, Emergency medical services, Delivery of Health Care

Posted Date: August 23rd, 2019

DOI: https://doi.org/10.21203/rs.2.13536/v1

License: () (7) This work is licensed under a Creative Commons Attribution 4.0 International License. Read Full License 


\section{Abstract}

Background: Comprehensive health care delivery is a major challenge for the Brazilian Unified Health System. Inadequate coordination among different health care levels and facilities produces poor access to health care and low degree of integration across levels of care, that is worse in emergency care delivery. Health policy has focused on health care networks development and regulation of access to health care provision. In the city of Rio de Janeiro, local health policy has prioritized the development of an Emergency Care Network. This research aimed at assessing the access to hospital beds and diagnostic resources, fundamental to continuity of care this network. Methods: Triangulation technique was employed, collecting of data from different sources and analysis resorting to multiple methods. Analysis of data from primary and secondary databases was performed. Interviews were conducted with managers and healthcare professionals involved in guaranteeing continuity of care in Emergency Care Network. Data analysis resorted to descriptive statistics and the interviews along with the data were interpreted under the conceptual framework of Integrated Health Care. Results: Poor access to hospital beds constituted a major obstacle to improvements in continuity of care for patients in Emergency Care Network. An insufficient number of hospital beds is the primary issue. Other aspects of hospital care contribute to aggravate this deficiency: the predominance of general hospitals, the existence of small and underequipped hospitals, prolonged lengths of stay and significant discrepancies of bed occupancy rates among specialized and general hospitals. Hospitals further face disrupted internal workflows due to inadequacy and limited availability of human and physical resources. Moreover, weak cooperation between federal, state and local government leads to persistence of a fragmented network with little or absent interaction among health care facilities and professionals from different government spheres. Conclusion: To reach a better degree of integration among health services in the city of Rio de Janeiro investments in hospital capacity and quality are needed in order to meet health care necessities. Besides, federal, state and local government need to find common ground concerning each ones' duties in health care delivery to achieve better results in providing comprehensive health care.

\section{Background}

Health services in Brazil are largely provided by the Sistema Único de Saúde (SUS), or Unified Health System, created in 1988, having as core principles universality, comprehensiveness and equality. Since its foundation, the Brazilian Unified Health System has faced uninterrupted constraints on investment and funding that continuously compromised access to and provision of health care, due to insufficient and poorly maintained infrastructure and undersized and unqualified human resources. The healthcare system reflects the three-tier federative system composed of the central government, 27 states and thousands of municipalities, in which substantial regional and social inequalities abound. Such organizational structure results in multiple health authorities and much uncertainty concerning roles and responsibilities, which are either not clearly sorted out among the different governmental levels or simply not accounted for. In addition, political cycles hamper long-term planning and health care management is largely performed by untrained managers. This arrangement yields considerable obstacles to the structuring of integrated health care services and to the redesign of the health care model from a hospital-based care to a primary care-driven provision of health care ${ }^{1}$. Despite the difficulties outlined, over the last two decades the system has undergone a major increase in access to health care services, mainly due to primary care expansion, both in terms of coverage and scope of practice ${ }^{2}$.

Since the 2000s the development of an Emergency Care Network has featured prominently in Brazil's federal health agenda, with significant funding support to expand health care facilities, especially for prehospital care units like the Serviço de Atendimento Móvel de Urgência (SAMU), or Mobile Emergency Medical Services, and Unidades de Pronto Atendimento (UPA), or Emergency Care Units ${ }^{3,4,5}$.

Regulatory mechanisms to organize access to the existing health care services or to size up its provision in order to meet the population's health needs, either in national or local level, constitute a decisive issue to the effectiveness of the Brazilian Unified Health System ${ }^{6}$. Thus, regulation of access to these services is singled out as a major problem. The lack, inadequacy or inefficiency of regulatory mechanisms pertaining the access to health services are the many forms of the problem. Hardships are found at different health care levels. Primary care assistance generally struggles with long waiting times to specialist's consultation and to high-cost diagnostic tests. Emergency care provision is also considerably hindered by the difficulties faced by SAMU and UPA in obtaining support from overcrowded emergency departments or obtaining admission to hospital beds, which are usually not available.

Among the numerous regulatory mechanisms envisaged by national policy on the subject of health regulation, the creation of the Centrais de Regulação, centers that organize the access to health services, prioritizing demands according to health needs and services availability, stands out as a relevant resource to overcome difficulties related to teamwork and work flows established among SAMU, UPA and hospital emergency departments ${ }^{7}$. These centers potentially improve the coordination of care delivered by multiple providers through the development of negotiated agreements, boosting compromise and cooperation and highlighting interdependence ${ }^{7}$. Nonetheless, the deficient provision of outpatient services considerably burdens the Emergency Care Network leading to emergency care overuse, a high workload significantly comprised of severely ill patients and hospital emergency departments overcrowding ${ }^{8,9,10}$.

The unstable and insufficient availability of diagnostic test, high-cost therapies, specialists consultation and hospital beds to convey continuity of care constitutes a major impediment to the development of an effective Emergency Care Network, as pointed out by numerous studies $3,11,12,13,14,15,16,17,18$.

Regulation of access to hospital beds is one of the most important tasks of the Centrais de Regulação, especially when considered the prevailing and international phenomena of hospital emergency department overcrowding, which is mainly due to prolonged length of stay in the emergency department. In developed countries the protracted length of stay is largely explained by a high hospital bed occupancy rate, making hospital beds unavailable to hospital admission. Conversely, in Brazil, hospital emergency department overcrowding is mostly a result of the inadequate provision of ambulatory care, leading to emergency departments overuse, and a poor hospital performance, leading to long lengths of stay 19,20,21,22,23,24,25,26,27.

Moreover, secondary, tertiary and emergency care, as well as the majority of specialized ambulatory care, is performed in hospitals, securing this facility a key role in Brazilian Unified Health System, because they cluster much of the high-cost medical technology and specialized human resources ${ }^{28}$. 
Despite all achievements delivered by the Brazilian Unified Health System in its 40 years of existence, the outcomes are still vulnerable to austerity measures, that magnify the effects of chronic underfunding and increase the importance of the challenges like delivering health services through an integrated network and enhancing the interfederative governance mode ${ }^{29}$.

\section{Methods}

This research aimed at assessing how the access to hospital beds and diagnostic and therapeutic resources, fundamental to provide continuity of assistance in the Emergency Care Network, affects the development of integrated health care networks. This study was conducted within the Emergency Care Network of the city of Rio de Janeiro, Rio de Janeiro, Brazil. This network is composed of health care facilities managed by all three federative levels: municipal level, state level and federal level. The city was selected owing to its relevance in the national scenario, as the second largest in Brazil, to the authors engagement in the local health system and to the recent and robust expansion of the Emergency Care Network, carried out by policies that focused on emergency care ${ }^{4,5}$.

The Emergency Care Network is comprised of different types of health care facilities: the Centrais de Regulação, the Unidades de Pronto Atendimento (UPA), or Emergency Care Units, the Coordenações de Emergência Regional (CER), or Regional Emergency Centers, and General Hospitals. The Serviço de Atendimento Móvel de Urgência, or Mobile Emergency Care Services, is also part of the Emergency Care Network, but was not examined in this research. In the city of Rio de Janeiro there are two Centrais de Regulação: the Central Estadual de Regulação (CER-RJ), or State Access Regulation Center, and the Complexo Regulador do Município do Rio de Janeiro (CRMRJ), or Municipal Access Regulation Center. The UPA and CER are pre-hospital health facilities that can provide support to life threatening situations as well as medical attention to minor injuries and urgent medical ailments. The difference between these two facilities is that $C E R$ are physically close to and operate with a preferential support from their neighbor acute hospitals. The $C E R$ are units created and managed by the municipal administration, while UPA can be run either by state or municipal administration. As to hospitals is mandatory to have within its organization a group of workers appointed to oversee and control access to hospital's resources, called Núcleo Interno de Regulação (NIR), or Internal Regulatory Committee. These committees constitute the channel through which hospitals interact with other health facilities.

A triangulation technique was employed encompassing collection of data from different sources and analysis resorting to multiple methods, in order to fill in potential data gaps, to yield cross verification of data and to provide a more comprehensive understanding of a complex and little explored phenomena ${ }^{30}$.

Data was obtained by means of interviews and consultation of databases. Thirty-six interviews were held engaging managers and health care professionals. Among the managers there were one from federal administration, two state health managers and three from the municipal health department. Medical regulators, that is physicians performing regulatory activities, were interviewed during visits to the Centrais de Regulação, one at the State Access Regulation Center and three at the Municipal Access Regulation Center. Members of hospitals' Internal Regulatory Committee were interviewed in 5 different hospitals: two municipal hospitals, one with and one without an emergency department, a state and a federal hospital with emergency departments and a teaching hospital without an emergency department. Physicians engaged in regulatory activities were also interviewed at the UPA, which amount to 30 in the city of Rio de Janeiro. A total of 16 interviews were conducted, being half of them in municipal Emergency Care Units and the other half in Emergency Care Units managed by the state government. Five Regional Emergency Centers were visited and interviews with physicians involved in regulatory activities were performed.

Access to hospital beds was assessed through data obtained from the two systems used in CRMRJ to perform the allocation and distribution of hospital beds: the Sistema de Regulação (SISREG), or National Regulatory System, and the Plataforma SMS-Rio, or Municipal Regulatory System. Access to these systems was officially authorized by the municipal health department. Health facilities place hospital bed requests through these systems via online access. The request form filled in on SISREG website contains the patient's name, medical diagnosis, short clinical report and type of hospital bed requested. Upon the acceptance of the request for a hospital bed, health care facilities get a response through SISREG and e-mail. Medical regulators at CRMRJ work primarily on Plataforma SMS-Rio because of its more suitable resources to manage and sort out data from hospital bed request and municipal hospitals occupancy rates in order to provide the most efficient allocation. From SISREG it was possible to verify whether or not access to a hospital bed had been granted, consulting each form request at a time. Only from Plataforma SMS-Rio it was possible to obtain the total number of hospital beds to which access was granted. Unanswered requests placed on SISREG were not available at Plataforma SMS-Rio.

The data imported corresponded to the period from September 2016 to August 2017. During this period, 56,907 hospital bed requests were placed on SISREG. During the same period, 10,750 hospital beds were regulated through the Plataforma SMS-Rio. A data analysis was carried out with the construction of the frequency distribution of the hospital bed requests according to several variables such as: type of the requesting health care unit (UPA, CER, hospital), administrative sphere of the requesting unit (federal, state, municipal), type of hospital bed requested (Internal Medicine ward, Surgery ward, ICU), type and administrative sphere of the health unit to which the hospital bed belonged.

From the imported data, two datasets were generated. A first dataset included all adult ICU bed requests placed on SISREG, either by a state UPA, a municipal UPA or a municipal CER. The second dataset included all the requests for admission to an Internal Medicine war bed placed by the same units. The UPA-CER ICU database encompassed 5,969 requests and the UPA-CER Internal Medicine dataset was comprised of 20,317 requests. For the ICU dataset a random sampling resulted in 590 requests to be analyzed and for the Internal Medicine database the same procedure resulted in 1001 requests to analyze. Each of these requests was consulted on SISREG through their request number in order to examine whether the outcome of the request had been access to a hospital bed or not. The state health department did not authorize access to the State Regulatory System database.

Data regarding hospitals was obtained by consulting two different databases: the National Health Care Facilities Registry (Cadastro Nacional de Estabelecimentos de Saúde - CNES) and the Health Indicators Database from the Health Informatics Department of the Brazilian Ministry of Health (DATASUS). Through the website of CNES all hospitals situated in the city of Rio de Janeiro which met the criteria of public ownership (natureza jurídica: 
"administração pública") and general-purpose functionality, that is general hospitals, (tipo de estabelecimento: "hospital geral") had its record consulted and the number of declared hospital beds computed according to type. This consultation yielded a total of 33 hospitals, 4 State hospitals, 17 Municipal hospitals, 6 Federal hospital and 3 Teaching hospitals. Hospitals were coded according to ownership and numbered by alphabetical order. Thus, State Hospitals are coded SH1-SH4, Municipal Hospitals are coded MH1-MH17, Federal Hospitals are coded FH1-FH6 and Teaching Hospitals TH1-TH3.

In order to estimate hospital performance two indicators were selected: mean length of stay and hospital bed occupancy rate. The data on length of stay was readily available at the database from the Health Informatics Department (DATASUS). Conversely, hospital bed occupancy rates were not available and had to be calculated. According to official norms ${ }^{31}$ bed occupancy rate is calculated using information gathered locally at each hospital. Since this was not feasible, an alternative to the official formula was employed to reach an approximation. The rate of hospital bed utilization was calculated by means of the following formula: total hospital admission multiplied by the mean length of stay divided by the total hospital bed number multiplied by the total number of days, for a given period of time. The total number of hospital admissions was obtained through DATASUS. The search strategy encompassed the period of time between September 2016 and August 2017 and was restricted to public hospitals of the Brazilian Unified Health System located in the city of Rio de Janeiro. The search strings were crafted to elicit data meeting the following criteria: (a) mean length of stay per hospital covering all types of hospital admission; (b) mean length of stay per hospital covering only clinical hospital admission; (c) total number of hospital admissions per hospital covering all types of hospital admission; and (d) total number of hospital admissions per hospital covering only clinical hospital admission.

Data analysis resorted to descriptive statistics and the contents of the interviews along with the data were interpreted under the conceptual framework of Integrated Health Care and Health Systems Governance $32,33,34$.

\section{Results And Discussion}

Over the last decade state and municipal government have made substantial investments in the development and improvement of the Emergency Care Network in the city of Rio de Janeiro, with a strong emphasis on boosting regulatory mechanisms besides the expansion of Emergency Care Units ${ }^{4}$. The creation and reorganization of the Centrais de Regulação on municipal and state level, empowered with authority to decide over the allocation of resources was a central managerial decision. The number of managers and health professionals overseeing regulatory processes increased. Information technology was intensively used in order to facilitate and broaden the regulation of access to health care resources, like hospital beds and consultation with specialists. A transition from regulation based on personal relationships or contacts to a more institutionalized regulatory practice was firmly pursued, expecting to challenge the power hospitals have over their beds. Much effort was employed to eliminate redundant and parallel procedures, to centralize work and information flows, to curtail personal interferences, to enhance expertise and to advance a paradigm shift towards cooperation and integration.

From the interviews and datasets analyzed the hospital sector and the local health system segmentation stood out as major issues that undermine the effectiveness of regulatory mechanisms and forestall the development of integrated health care services.

\section{Hospital sector}

Access to hospital beds emerged as a central issue for the adequate performance of the Emergency Care Network. In all interviews conducted this problem was highlighted as a major obstacle. Among the many problems elicited, an undersized hospital capacity, with an insufficient number of hospital beds, was the most pressing issue. However, undefinition or restrictions of the type of care provided by hospitals, low hospital performance and management problems, especially concerning human resources and infrastructure, were also pointed out as relevant aspects.

The biggest problem was the insufficient number of hospital beds, especially to fulfill the demand from the emergency departments. In the twelve-month period examined in this research, 24,564 requests were placed for hospital beds in Internal Medicine wards via SISREG. This number encompasses requests placed by municipal, state and federal health care facilities in the city of Rio de Janeiro. During the same period the $C R M R J$ was able to obtain a bed to only 3,239 of the requests placed for Internal Medicine wards, resulting in $86.8 \%$ of unanswered requests. For Intensive Care Unit beds the situation was even more dire, 8,310 requests were placed in SISREG, but only 936 requests obtained a bed via CRMRJ, leaving $88.7 \%$ of the requests unmet.

\section{(Table 1)}

A national research that assessed the implementation of the UPA, indicated that access to hospital beds was the major constraint to these units' performance. Difficulties to get patients admitted to hospitals were persistent and led to distortions of the work performed and of the care provided by these units ${ }^{17}$.

The network of public hospitals located in the city of Rio de Janeiro holds 1,305 hospital beds in Internal Medicine wards, considering only the General Hospitals administrated by the three governmental levels, including Teaching Hospitals. Of these, 726, 243 and 190 are under municipal, federal and state administration respectively. In Teaching Hospitals there are 146 additional beds labelled "Internal Medicine". Another 685 hospital beds are intended for curative care for specific medical specialties, like: Dermatology, Gastroenterology, Hematology, Nephrology, Neurology, Oncology, Pneumology, Tuberculosis, Burns Units and Mental Health. Psychiatric beds and beds from Specialized Care Institutes and Hospitals were not included. Hospital beds in Surgery wards amounted to 2,214, further subdivided among surgical specialties (table 1).

In the city of Rio de Janeiro there is only 0.2 public Internal Medicine ward beds available per 1,000 inhabitants, according to data from table 1 and from the 2010 Census, which estimated a population size of 6,320,000 million for the city of Rio de Janeiro. It is important to highlight that this estimate does not consider the part of the population that uses private health care plans and insurances, which tend to use private hospital beds. This might overestimate the size of the population that actually demand public hospital beds. However, in emergency care situations, even these citizens with access to private medical 
care may come to use these beds. Conversely, Federal Hospitals and Teaching Hospital beds are expected to be available to citizens from others cities within the State of Rio de Janeiro, which could further decrease this estimate. Specialized Care Institutes and Hospitals were not considered, because access to its beds is being regulated through ambulatory care, by means of outpatient waiting lists.

On national level the scenario is equally one of scarcity. In 2014, there were 2.19 hospital beds per 1,000 inhabitants including all hospital beds from public and private hospitals. When considering only public hospital beds this number falls to 1.56 hospital beds per 1,000 inhabitants. Both numbers are way below the average of 3.5-4.0 hospital beds per 1,000 inhabitants found among OCDE countries ${ }^{35}$. When examining only the hospital beds properly served with an adequate number of health care professionals and compatible medical technology and physical resources, which grossly correlates to hospital size, the hospital bed gap grows deeper, falling from 1.56 to 0.7 hospital beds per 1,000 inhabitants in SUS ${ }^{35}$.

Intensive care unit beds depict an even more critical situation in the municipality of Rio de Janeiro, with 0.07 public ICU beds per 1,000 inhabitants. In 2014 , there were 12,680 Adult ICU beds available to SUS, among public, philanthropic and private providers ${ }^{35}$. Considering that, in 2014 , the Brazilian population was of $202,768,562$ million inhabitants ${ }^{36}$, on national level there was as little as 0.06 public Adult ICU beds per 1,000 inhabitants. Internationally, around 0.20 to 0.25 intensive care beds per 1,000 inhabitants is considered acceptable ${ }^{37}$. In Europe, in 2011, there was on average 0.11 ICU beds per 1000 inhabitants ${ }^{38}$.

In a research that sought to define the number of public Adult ICU beds required to meet the existing demand, an analysis restricted to the ICU beds regulated by $C E R-R J$ identified that, to guarantee a stable system and a maximum waiting time of 6 hours to reach an ICU bed, the existing number of ICU beds should be doubled, if maintained the average length of stay in intensive care units ${ }^{39}$.

A specific example of this scenario of insufficiency is the acute myocardium infarction (AMI) care pathway. In several situations it is necessary to perform primary or rescue coronary angiography. Interviews reported that access to this intervention is restricted to specific cases and frequently take various days to occur. Specialized Care Institutes and Hospitals in which this intervention can occur, perform the procedure, but do not admit these patients to a hospital bed for immediate follow-up. Therefore, patients that succeed in undergoing coronary angiography have to return to the UPA or CER, and are later discharged from these same pre-hospital units. If in the one hand this arrangement has somewhat increased access coronary angiography, which has an important impact in decreasing AMI morbimortality, on the other hand there are problems in providing post-procedure care in pre-hospital setting, that is in UPA and CER, for these units are neither trained or fit to do so, since they lack the resources and knowledge do deal with potential complications.

A research conducted in the city of São Paulo demonstrated that the organization of a specific pathway to provide health services for AMI patients had a significant impact on disease morbimortality ${ }^{40}$. Thus, the arrangements established fore AMI care in the city of Rio de Janeiro as outlined above are unsuitable for the serious public health care issue that this disease represents. Even if the provision of coronary angiography in a pre-hospital setting is acknowledged as an increase in access to health care, its availability is unpredictable and its performance conditions are far from adequate. Proper management of AMI cases, because of its high prevalence and high morbidity and mortality, requires integration between different levels of the health care system. The absence of such integration considerably contributes to increase morbidity and mortality ${ }^{40}$.

The health facilities that more frequently granted CRMRJ access to their hospital beds during the period of this research are listed in table 2. Pediatric, psychiatric and OB-GYN beds were not included. The top five hospitals that made their hospital beds available to $C R M R J$ accounted for $75,5 \%$ of all the requests that were met. It is noteworthy that these hospitals did not have emergency departments. Municipal hospitals with emergency departments made hospital beds available in varying degrees, from 2 beds yielded by $\mathrm{MH} 13$ to 225 beds yielded by $\mathrm{MH} 6$. Federal administration made available only 53 beds to CRMRJ in 1 year. Among the Teaching Hospitals, only TH3 made 12 beds available. It is noteworthy that a pre-hospital unit, has ICU beds registered in the National Registry, that were made available to CRMRJ.

(Table 2)

Brazil has an obsolete hospital system, in which predominate general purpose hospitals, of small and medium size, that provides acute, elective and long-term care, indistinctly. Patients with different health needs are all counting on an indisputably small hospital capacity of 1.56 beds per 1,000 inhabitants offered by sus $S^{35}$.

Among the hospitals in the municipality of Rio de Janeiro, there is a similar situation. Frequently the same hospital offers emergency care, elective surgical procedures and ambulatory care simultaneously. These hospitals constantly face the challenge to reconcile the tasks of an acute care hospital with the modus operandi and structure of a specialized hospital. In this situation, the same hospital bed is requested by an overcrowded emergency department and also by the long waiting list to elective admission, mostly to perform surgical procedures.

In 2012, the city administration created the CER in order to address overcrowding in the emergency departments of municipal hospitals. These units became responsible for all medical emergencies while the emergency departments of their neighbor acute hospitals focused on accident and trauma emergencies. These units were constructed in separate buildings and had their own health care staff, which represented an expansion of human and physical resources for emergency care.

A selection of 10 diagnostic and therapeutic resources available in public hospitals in the city of Rio de Janeiro is displayed in table 3 . The number of Internal Medicine ward, Surgery ward and ICU beds and the existence of emergency departments is also presented for each hospital. Since all facilities possessed electrocardiogram devices and X-Ray equipment to perform simple radiographs these were not included. This table shows that a higher availability of medical technology is found precisely in hospitals that have a larger bed capacity and also emergency departments.

(Table 3) 
Comparing data from the tables 2 and 3 it is striking that, among the five hospitals that more frequently made beds available to CRMRJ, only 2 have a high availability of medical technology: MH5 and MH15. Both count on a reasonable array of medical technology, but neither have a CT Scan in their premises. The remaining 3 hospitals of the top 5 rely on very little medical technology. MH3 and MH10 offer only Doppler Ultrasound aside from X-Ray and EKG equipment. A similar circumstance is found in other hospitals: under state administration, $\mathrm{SH} 1$ and $\mathrm{SH} 3$ count on the same type of devices as MH3 and MH10. At municipal level, MH14 adds an Echocardiogram device to the previous set of equipment. In this scenario of low medical technology availability, these hospitals have a limited capacity to provide curative care, thus narrowing the range of health problems and disease severity they can care for.

Most municipal hospitals count on a good array of medical technology including CT scans, but many of them preferably admit to their beds patients waiting in their own emergency departments. The same happens with the two state hospitals that have emergency departments, $\mathrm{SH} 2$ and SH4.

While the hospital beds needed are expected to provide care to a large variety of health issues and problems, it is not unusual to find hospital beds whose availability is restricted to certain types of diseases. In some cases, this results from the restricted availability of medical technology as referred to before, but in other cases, especially in Teaching and Federal hospital, chief of services, without acknowledging the population health needs, decide alone the scope of care their service is providing.

In addition to the difficulties outlined thus far, a few hospitals exhibit a mismatch between their prevailing type of hospital beds, mostly surgical beds, and their predominant workload, mostly clinical emergencies, which often results in emergency department overcrowding.

A study on the definition of the functional typology of Federal Hospitals in the city of Rio de Janeiro observed that this process is barely rational and systemic and that change is largely driven by the urge to solve problems instead of deriving from planned action to render the hospital more efficient and integrated to the network of health care services. Each hospital incorporates technology and seeks to answer to health needs independently, ascribing their behavior to an allegedly disorganization of the local health system that hampers the possibility of mutual adjustment in order to reach integrated care. The discourses of resistance to change perceived in these hospitals demonstrate that the power dimension within these organizations needs to be considered in order to shape strategies to revise the functional typology of these hospitals ${ }^{41}$.

Another study also corroborates the existence of difficulties for the integration of hospitals in the $R U E$, evidencing that this process requires the definition of pacts and care flows, adequate functioning of other health services in the network, especially Primary Care Services, efficient regulation of access to services, and engagement of hospital managers and professionals ${ }^{42}$.

Regarding hospitals' performance, a heterogeneous dynamic has been observed with significant variations in the average length of stay and hospital bed occupancy rate. Table 4 presents the total number of hospital beds and hospital admissions, the total number of Internal Medicine beds and hospital admissions due to clinical diagnosis. The table also shows the average length of stay and the hospital bed occupancy rate.

(Table 4)

International standards recommend a hospital bed occupancy rate between 75 and $85 \% 35,37,43$. In table 4 it is noteworthy that few hospitals meet this pattern. Most of the hospitals that have emergency departments operate with occupancy rates way above: $\mathrm{MH} 2$ 92\%, MH8 173\%, MH9 112\%, MH11 127\%, MH13 169\%, MH16 103\%, MH17 106\%, FH2 93\% and FH5 86\%. Occupancy rates higher than 85\% increase risk to patients and in acute care hospitals rates higher than $90 \%$ denote a bed shortage crisis ${ }^{35}$. Conversely, most hospitals that do not have emergency departments exhibit occupancy rates below $75 \%$, which suggests underuse of beds and resources. Teaching hospitals and Federal hospitals without emergency departments display predominantly this pattern.

The average length of stay is long for most hospitals, a previously known problem. Considering all the hospitals listed in the table 4 , the average length of stay is of 8 days, consistent with the OECD average in $2015^{44}$. However, when examining hospital admission due to clinical diagnosis separately the average LOS increases by 4 days, reaching 12.6 days. Calculating the average length of stay of hospitalizations due to clinical diagnosis for each administrative level, the results are the following: 9.5 days for municipal hospitals, 7.75 days for municipal hospitals, 15.4 days for federal hospitals, and 12.5 days for teaching hospitals. Considering only the hospitals that have emergency services (7 municipal, 2 state and 3 federal) this average drops to 10.5 days.

The hospital sector performance was considered problematic and represented an additional element to accentuate the shortage of beds according to some UPA coordinators who also worked or had worked in the hospital sector. Long average lengths of stay are explained by several limitations of hospital operation.

Among them we have: reduced operation at night and on weekends, primarily due to reduced availability of consulting physicians and diagnostic services. The availability of diagnostic services may actually be a critical issue for hospital efficiency. A study that sought to analyze the reasons for delayed hospital discharge of patients in internal medicine wards of teaching hospitals identified as one of the main reasons for this problem the long delays to perform diagnostic tests or to release tests reports ${ }^{45}$. Other factors related to delayed hospital discharged included: a more time-consuming decision-making process due to longer discussion over clinical case in teaching hospitals as well as difficulties in obtaining specialists opinion on cases ${ }^{45}$. However, the most common scenario is the absence of a daily ward routine performed by a single consultant. Instead, the care plan is devised each day by physicians and health teams working shifts, who may be unexperienced or unqualified, resulting in longer lengths of stay, misdiagnosis and ineffective treatment. 
Besides all the hardships previously outlined, existing hospital beds can become unfit for admission due to physicians and nurse shortages or else due to neglected maintenance: infrastructure in need of repair and damaged equipment.

Within the municipal administration, it is already acknowledged that, in a scenario of chronic scarcity and prolonged financial constraints, the improvement of working processes is fundamental to increase access to existing resources. In this sense, the reduction of the average length of stay is one of the goals to be implemented, through optimization of health care provision.

The emergence of NIR promoted the expansion of the regulatory culture that succeed, little by little, in confronting hospitals' self-centered behavior in relation to becoming part of the health care network. It also contributed in making hospitals recognize their performance and efficiency problems. The progressive organization of the network and the growth of the regulatory culture forced hospitals and their teams to start perceiving themselves as a part of the system, having to share responsibilities.

The idea that chiefs of services have unquestionable control over admission to the wards under their responsibility is still appreciated by many, which lead hospitals to neglect their expected and potential role in an integrated health services network when organizing its operation.

Despite have being drafted in norms form many years now, only recently NIRs have been enacted in the city of Rio de Janeiro. Thus, these committees still have little power to oversee access to hospitals' resources. Support from the board of directors is critical for the NIR to perform its tasks. The extent to which they succeed in attending requests placed by CRMRJ, for hospital beds and diagnostic tests, depends on how hospitals perceive themselves within the network and how high-level managers from Health Department understand the importance of regulatory mechanism and the role of the hospital for accomplishing the goal of an integrated health system. Often even with the support of the board of directors, NIRs persist requiring authorization from chiefs of services to grant $C R M R J$ access to hospital beds.

In the process of building and structuring SUS, hospital sector was continually neglected. The elevated investment costs required to improve hospital sector, coupled with the process of expansion of outpatient care, underpinned by an overcritical discourse to the hospital-centered model, culminated in a problematic scenario in which the Brazilian hospital sector is predominantly small in size and inefficient in the provision of care $^{37}$.

National studies on the implementation of prehospital care in Brazil that analyzed the SAMU and the UPA pointed out serious issues concerning lack of support from hospitals and emergency departments, in terms of access to diagnostic tests and hospital admission, that significantly impacted the mission and performance of these facilities to deliver prehospital emergency care ${ }^{17,18}$.

In the case of Rio de Janeiro, as mentioned, there is an obsolete and fragmented hospital network, with serious management problems within its hospitals. In spite of the managerial technologies incorporated, especially with regard to regulation of access to care, the hospital network remained largely unchanged before the expansion of access to health care was made possible by improvements in the structuring of the RUE. MH6 was inaugurated in March 2013 , at the time with 120 beds, and can be cited as one of the few changes undergone by the hospital sector in the city of Rio de Janeiro. Another was the ICU bed expansion that ensued, with 33 new beds with the creation of a specific CER in the South Zone of the city in August 2012 and 38 new beds at MH2 in August 2015 , from 30 to 68 . Despite these measures, scarcity is still the dominant condition.

Over the last 10 years state health policy has strongly focused on the expansion of the Emergency Care Network, with the creation of numerous UPA. Nonetheless, the creation of Brain Institute, Children's Hospital and Orthopedics Hospital express investments in the provision of inpatient and outpatient Specialized Care. In addition, a foundation to manage human resources for health care was created to overcome legal constraints to employ public servants, which allowed an increase in the number of health professionals, mainly in Specialized State Institutes for Endocrinology and Cardiology.

The public hospital, notably in the example of Rio de Janeiro, continues to be a locus of technological concentration, whose importance has not declined with the incorporation of technological advances in outpatient care, since access to medical technology in an outpatient setting is still very fragile in the municipality. Outpatient access to diagnostic tests, specialists' referrals and pharmaceuticals is insufficient and incompatible with the trend of progressive reduction of hospital beds observed in Brazil ${ }^{35}$.

Other factors render the inadequacy of the hospital sector and the gaps in the provision of care in the system as a whole even more acute. Population ageing constitutes a major challenge for health systems, which in Brazil's case is greatly accentuated by a situation of significant social vulnerability, derived from profound socioeconomic inequalities.

The hospital network of the city of Rio de Janeiro, considered all the 30 hospitals, of table 1, is comprised predominantly of large and medium sized hospitals. There are 14 large-size hospitals (more than 150 beds), of which 6 have emergency departments, and 12 medium-size hospitals (between 50 and 150 beds), 5 with emergency departments. The predominance of large-size hospitals in the network is a positive characteristic, especially when observed that these hospitals cluster most of the medical technology, medical specialists and pharmaceuticals available in SUS. However, this favorable aspect is overshadowed by the significant number of such hospitals that provide emergency care. These hospitals face the challenge of reconciling the demand arising from overcrowded emergency departments and the requests of access to hospital beds and diagnostic tests placed by primary care services, prehospital services and small-size hospitals, via CRMRJ or CER-RJ. This dilemma remains unsolved and hinders the integration of these hospitals with the network health services. One of the managers interviewed in this study calls for an urgent remodeling of the hospital sector in order to better organize care, obtain the best performance from the existing hospitals and accommodating the emerging and growing demand for long-term care.

Hospital sector is complex and expensive. Costs to invest and remodel are high, as well as to maintain and improve. The recent successful development of $R U E$ made explicit the need to expand the size of the hospital sector. However, increase of hospital services capacity could be attained through improvements 
in hospital performance and operation, which in face of prolonged financial constraints, might be the only path available to strengthen hospital sector within SUS.

\section{Health System Segmentation}

In addition to the analysis of the hospital sector presented thus far, the segmentation of the local health care system and the overlapping of services stand out as issues that further aggravates the situation.

In the city of Rio de Janeiro, this overlapping has its origins in the first half of the twentieth century, when the public health system was comprised of the municipal hospitals (Rio de Janeiro was the federal district at the time), open to all citizens, and of the Social Security Institutes for Medical Assistance that provided medical care only to those that were regularly employed. Later theses institutes were incorporated by the federal administration, being run by the federal government since then. Over time state administration also took over some hospitals when the city ceased to be the federal district.

Tense and conflictive federative relations between state and municipal administrations in the city of Rio de Janeiro is an old and well-known problem, mainly derived from both the presence of state and federal health facilities in the municipal territory and from the burden derived from providing emergency care to the population of bordering cities, without the regional political action expected from state administration ${ }^{46}$. Besides, the municipal administration continuous quest to establish direct relations with federal administration, overlooking state administration role and actions add to forestall the formation of an effective and integrated network of health services. The persistence of unresolved conflicts sustain a distancing of state and municipal administrations, which hinders policy debate and cooperation to develop an integrated health system ${ }^{46}$.

Despite the transfer of three general hospitals that provided emergency care, located in the West Zone of the city, from state to municipal administration, which resulted in the majority of emergency hospital services being managed by the municipal health department, attenuating services segmentation and enhancing integration, the phenomenon of conflictive and distant relations among the government levels remains largely unchanged. This produces important implications for the operation of the network, with little integration of regulatory mechanisms and significant overlap of health care provision. As a result, health care facilities struggle to deliver reasonable performance and patients are deprived of timely access to health care. Municipal and state health care facilities have little access to beds and resources from each other and federal hospitals still operate mostly independently from the health care network as whole.

The segmentation of the network is elicited in table 5 . In the sample of ICU bed requests, from the 50 requests placed by state UPA through CRMRJ that were granted access to a hospital bed, $78 \%$ were beds in state hospitals, while only $8 \%$ were beds in municipal hospitals. From the 185 requests placed by either a municipal UPA or CER through CRMRJ that were granted access to a hospital bed, $91 \%$ were beds in municipal hospitals, while only $1.6 \%$ were beds in state hospitals. In the sample of Internal Medicine ward beds requests (table 5), from the 16 requests placed by state UPA that were granted access to a hospital bed, $43 \%$ were beds in state hospitals and another $43 \%$ were beds in municipal hospitals. From the 345 Internal Medicine ward beds requests placed by municipal UPA or CER that were granted access to a hospital bed, $95 \%$ were for municipal units. CRMRJ had no access to beds in state hospitals. It can be noticed that state UPA had access to both state and municipal hospitals, while municipal UPAs had access to only 3 state hospital beds.

\section{(Table 5)}

The federal hospital system in the city of Rio de Janeiro, which harbors a large amount of the medical technology available in the local health system, does not operates with effective regulation of access to its beds and barely acknowledges its crucial role in the Emergency Care Network. Over the last few years, the federal hospital system has been continuously compelled to become integrated to the health care network. However, the federal administration has largely retained its autonomy in the management of its hospital beds. This autonomy of the federal hospitals in relation to the network is also seen in the interaction among the federal hospitals.

The development of networks requires the recognition of the interdependence of actors and organizations, since none of them has all the resources and skills necessary to solve the health problems of a population in its various life cycles ${ }^{32}$. This understanding about the development of networks converges with the concept of governance as the decision-making process and the process by which decisions are implemented or not. Conceived in this way, governance analysis should focus both on the actors involved in the decision-making and implementation process, and on the conditions and structures created for the effectuation of the decisions made ${ }^{33}$. The possibility to solve a coordination problem in face of conflict is contingent by the nature and / or existence of governance structures ${ }^{34}$. The health care facilities involved in shaping the RUE, UPA and CER more than hospitals, experience very acutely this interdependence on a daily basis and recognize the need for integration in order to offer better and broader access to care for patients. The mechanisms of cooperation and coordination put into practice in this network have aimed at improving the management of resources, so tragically scarce, although mostly within each administrative sphere. No systematic mechanisms for creating and maintaining common governance are being adopted. Actors and organizations persist working separately, far from pursuing coordination of their interdependence for a collective project.

A limitation of this study is that complementary and decisive subjects to the challenging task of developing Integrated Health Services like health care financing, human resources management model and physicians' central role in the accomplishment of integration were only superficially examined.

\section{Conclusions}

The recent developments in the regulation of access to health care provision that took place in the Emergency Care Network of the city of Rio de Janeiro secured improvements through the implementation of centralized pathways to promote transparent and fair distribution of scarce resources and utilization of 
scientific and negotiated criteria to allocate procedures and hospital beds. However, the regulatory mechanisms to organize access to health care seem rather to seek an optimization of the existing resources, falling short from inducing a remodeling of services. This research succeeded in displaying that the limited accomplishments of the experience examined can be ascribed to a combination of two prominent elements: insufficient funding, human and physical resources coupled with conflicting and fragmented institutional and governmental interplay.

Funding and infrastructure available to meeting the health system principles and people's health needs never did suffice in Brazilian Unified Health System. As outlined in this study, the hospital sector depicts well the scenario in which outright lack of resources or shortage of health professionals is greatly aggravated by an incompetent and fragmented managing of the existing health care resources and facilities. In Rio de Janeiro, as in most of Brazil, public hospital beds are far from being sufficient. Moreover, the average hospital is an old, small to medium size, general-purpose hospital expected to offer acute, elective and chronic care simultaneously. In the city of Rio de Janeiro, the majority of hospitals was built during the 70s and has never undergone any restoration. Approximately half of them account for most of the high-technology diagnostic and therapeutic resources.

The challenging and troublesome interplay between the governmental spheres that put the local health system to effect, due to the different levels of expertise displayed by each executive level, was also demonstrated. Furthermore, the interaction among managers and authorities is frequently tarnished by political interests, hindering efforts to administer cooperatively responsibilities, resources and power, paramount to achieving shared governance, which considerably constrains the possibility of a faster and sustained expansion and improvement of the health services network.

The present research offers an analysis that contributes to a broader and deeper understanding of the issues of hospital bed shortage, poor hospital performance and the interfederative model for health delivery, highlighting its repercussions on the advancement of Health Care Networks and the improvement of Emergency Care and Hospital sector, crucial matters to the Brazilian Unified Health System. Further studies are needed to address intergovernmental relations impact on the experiences of regulation of access to health care facilities and procedures in other big cities.

\section{Abbreviations}

AMI: Acute Myocardial Infarction

CER: Regional Emergency Center (Coordenações de Emergência Regional)

CER-RJ: State Access Regulation Center (Central Estadual de Regulação)

CRMRJ: Municipal Access Regulation Center (Complexo Regulador do Município do Rio de Janeiro)

ICU: Intensive Care Unit

LOS: Lenght of Stay

NIR: Internal Regulatory Committee (Núcleo Interno de Regulação)

RUE: Emergency Care Network (Rede de Atenção em Urgência e Emergência)

SAMU: Mobile Emergency Medical Service (Serviço de Atendimento Móvel às Urgências)

SISREG: National Regulatory System (Sistema de Regulação)

SUS: Unified Health System (Sistema Único de Saúde)

UPA: Emergency Care Units (Unidades de Pronto Atendimento)

\section{References}

1. Paim JS. Thirty years of the Unified Health System (SUS) (Sistema Único de Saúde (SUS) aos 30 anos). Ciênc. saúde coletiva. 2018 June; 23 ( 6 ): $1723-$ 1728.

2. Viacava F, Oliveira RAD, Carvalho CC, Laguardia J, Bellido JG. SUS: supply, access to and use of health services over the last 30 years (SUS: oferta, acesso e utilização de serviços de saúde nos últimos 30 anos). Ciênc. saúde coletiva. 2018 June; 23(6): 1751-1762.

3. O'Dwyer G, Konder MT, Machado CV, Alves CP, Alves RP. The current scenario of emergency care policies in Brazil. BMC Health Services Research 2013, 13:70

4. Lima LD, Machado CV, O'Dwyer G, Baptista TWF, Andrade CLT, Konder MT. Interdependence between government levels in Brazilian health policy: the implementation of emergency Care Units in the state of rio de Janeiro, Brazil (Interdependência federativa na política de saúde: a implementação das Unidades de Pronto Atendimento no estado do Rio de Janeiro, Brasil). Cienc. saude coletiva. 2015; 20(2): 595-606.

5. Konder MT, O'Dwyer G. The integration of the Emergency Care Units (UPA) with healthcare services in the city of Rio de Janeiro, Brazil (A integração das Unidades de Pronto Atendimento (UPA) com a rede assistencial no município do Rio de Janeiro, Brasil). Interface (Botucatu). $2016 ; 20$ (59):879-92.

6. Silva PLB. Serviços de Saúde: o dilema do SUS na nova década. São Paulo em Perspectiva. 2003; 17(1), 69-85.

7. Araújo MT, Alves M, Gazzinelli MFC, Rocha TB. Social representations of Emergency Care Unit professionals on Emergency Mobile Services (Representações sociais de profissionais de unidades de pronto atendimento sobre o serviço móvel de urgência). Texto contexto - enferm. 2011; 20(spe): 
156-163.

8. O'Dwyer G, Oliveira SP, Seta MH. Evaluation of emergency services of the hospitals from the QualiSUS program (Avaliação dos serviços hospitalares de emergência do programa QualiSUS). Ciênc. saúde coletiva. 2009 Dec; 14(5): 1881-1890.

9. Ohara R, Melo MRAC, Laus AM. Characterization of the care profile of adult patients of an emergency medical service (Caracterização do perfil assistencial dos pacientes adultos de um pronto socorro). Rev. bras. enferm. 2010 Oct; 63( 5 ): 749-754.

10. Dubeux LS, Freese E, Felisberto E. Access to regional emergency hospitals: approach to users to assess itinerary and obstacles to health services (Acesso a hospitais regionais de urgência e emergência: abordagem aos usuários para avaliação do itinerário e dos obstáculos aos serviços de saúde). Physis. 2013 June; 23( 2 ): 345-369.

11. Minayo MCS, Deslandes SF. Analysis of the implementation of a mobile pre-hospital treatment system in five Brazilian state capitals (Análise da implantação do sistema de atendimento pré-hospitalar móvel em cinco capitais brasileiras). Cad. Saúde Pública. 2008 Aug; 24( 8 ): 1877-1886.

12. Silva JG, Vieira LJES, Pordeus AMJ, Souza ER, Gonçalves MLC. Mobile pre-hospital care in Fortaleza, Ceará: the vision of professionals involved (Atendimento pré-hospitalar móvel em Fortaleza, Ceará: a visão dos profissionais envolvidos). Rev. bras. epidemiol. 2009 Dec ; 12 ( 4 ): $591-603$.

13. O'D wyer G, Mattos RA. The SAMU, the regulation in the State of Rio de Janeiro and integral care according to managers of the three government levels ( $O$ SAMU, a regulação no Estado do Rio de Janeiro e a integralidade segundo gestores dos três níveis de governo). 2012; 22(1): 141-160.

14. Lima DP, Leite MTS, Caldeira AP. Health Care Networks: the perception of physicians working in emergency services (Redes de Atenção à Saúde: a percepção dos médicos trabalhando em serviços de urgência). Saúde debate. 2015 Mar; 39(104): 65-75.

15. Torres SFS, Belisário SA, Melo EM. The emergency network in the northern macro-region of Minas Gerais, Brazil: a case study (A Rede de Urgência e Emergência da Macrorregião Norte de Minas Gerais: um estudo de caso). Saude soc. 2015 Mar; 24(1): 361-373.

16. O’Dwyer G, Machado CV, Alves RP, Salvador FG. Mobile prehospital emergency care: an analysis of implementation in the State of Rio de Janeiro, Brazil (Atenção pré-hospitalar móvel às urgências: análise de implantação no estado do Rio de Janeiro, Brasil). Ciênc. saúde coletiva. 2016 July ; 21 ( 7 ): 2189 2200.

17. O'Dwyer G, Konder MT, Reciputti LP, Lopes MGM, Agostinho DF, Alves GF. The process of implementation of emergency care units in Brazil (O processo de implantação das unidades de pronto atendimento no Brasil). Rev Saude Publica. 2017; 51:125

18. O'Dwyer G, Konder MT, Reciputti LP, Macedo C, Lopes MGM. Implementation of the Mobile Emergency Medical Service in Brazil: action strategies and structural dimension (O processo de implantação do Serviço de Atendimento Móvel de Urgência no Brasil: estratégias de ação e dimensões estruturais). Cad. Saude Publica. 2017; 33(7): e00043716.

19. Andrulis DP, Kellermann A, Hintz EA, Hackman BB, Weslowski VB. Emergency departments and crowding in United States teaching hospitals. Ann Emerg Med. 1991 Sep; 20(9):980-6.

20. Cameron P, Scown P, Campbell D. Managing access block. Aust Health Rev. 2002; 25(4):59-68.

21. Forster AJ, Stiell I, Wells G, Lee AJ, van Walraven C. The effect of hospital occupancy on emergency department length of stay and patient disposition. Acad Emerg Med. 2003 Feb; 10(2):127-33.

22. Fatovich DM, Nagree Y, Sprivulis P. Access block causes emergency department overcrowding and ambulance diversion in Perth, Western Australia. Emerg Med J. 2005 May; 22(5):351-4

23. Hoot NR, Aronsky D. Systematic review of emergency department crowding: causes, effects, and solutions. Ann Emerg Med. 2008 Aug; 52(2):126-36

24. Bittencourt RJ, Hortale VA. Interventions to solve overcrowding in hospital emergency services: a systematic review (Intervenções para solucionar a superlotação nos serviços de emergência hospitalar: uma revisão sistemática). Saude Publica. 2009 July ; 25(7): 1439-1454.

25. Moskop JC, Sklar DP, Geiderman JM, Schears RM, Bookman KJ. Emergency department crowding, part 1-concept, causes, and moral consequences. Ann Emerg Med. 2009 May;53(5):605-11.

26. Harris A, Sharma A. Access block and overcrowding in emergency departments: an empirical analysis. Emerg Med J. 2010 Jul; 27(7):508-11.

27. Grabois V, Bittencourt RJ. Emergency Department Overcrowding (Superlotação dos serviços de emergência). In: SOUSA, Paulo; MENDES, Walter. Segurança do paciente. Conhecendo os riscos nas organizações de saúde. Rio de Janeiro: Ed. Fiocruz, 2014.

28. Pires MRGM, Göttems LBD, Martins CMF, Guilhem D, Alves ED. Supply and demand of the medium-complexity/SUS: relation with primary health care (Oferta e demanda por média complexidade/SUS: relação com atenção básica). Ciênc. saúde coletiva. 2010 June; 15(Suppl 1): $1009-1019$.

29. Castro MC, Massuda A, Almeida G, Menezes-Filho NA, Andrade MV, de Souza Noronha KVM, Rocha R, Macinko J, Hone T, Tasca R, Giovanella L, Malik AM, Werneck H, Fachini LA, Atun R. Brazil's unified health system: the first $\mathbf{3 0}$ years and prospects for the future. The Lancet. 2019 Jul 11, 2019 http://dx.doi.org/10.1016/S0140-6736(19)31243-7

30. Deslandes SF. Revisitando as metodologias qualitativas nas pesquisas de avaliação: vertentes, contribuições e desafios. In: BAPTISTA, Tatiana Wargas de Faria (Org). Políticas, planejamento e gestão em saúde: abordagens e métodos de pesquisa. Rio de Janeiro: Editora FIOCRUZ, 2015. p. $193-217$.

31. Ministério da Saúde. Padronização da nomenclatura do censo hospitalar. 2 ed. Brasília: Ministério da Saúde. 2002. Available at: http://bvsms.saude.gov.br/bvs/publicacoes/padronizacao_censo.pdf

32. Hartz ZMA, Contandriopoulos A. Comprehensive health care and integrated health services: challenges for evaluating the implementation of a "system without walls" (Integralidade da atenção e integração de serviços de saúde: desafios para avaliar a implantação de um "sistema sem muros"). Cad. Saude Publica. 2004; 20 (2): S331-36.

33. Rodríguez C, Lamothe L, Barten F, Haggerty J. Governance and Health: Meaning and Implications in Latin America (Gobernanza y salud: significado y aplicaciones en América Latina). Salud Pública. 2010; 12 ( 1 ): 151-159. 
34. Gonzalez-Chavarria A. Multi-Agent Institutional Analysis: The Social Agency and Structuration Problem in the Explanation of the Emergence of Govemance Structures (Análisis institucional multiagente: el problema de estructuración y agencia en la explicación de la emergencia de estructuras de gobernanza). Rev Estud Soc. 2014; 49: 190-204. http://dx.doi.org/10.7440/res49.2014.14

35. Negri Filho AA. Bases para um debate sobre a reforma hospitalar do SUS: as necessidades sociais e o dimensionamento e tipologia de leitos hospitalares em um contexto de crise de acesso e qualidade. 2016. 366f. Tese (Doutorado em Medicina Preventiva) - Faculdade de Medicina, Universidade de São Paulo, São Paulo.

36. Instituto Brasileiro de Geografia e Estatística. Resolução n² 2, de 26 de agosto de 2014. Divulga as estimativas da População para Estados e Municípios com data de referência em $1^{\circ}$ de julho de 2014. Diário Oficial da União, Brasília, DF, 28 ago. 2014. p. 98.

37. Coelho IB. Hospitals in Brazil (Os hospitais no Brasil). 1st ed. São Paulo: Hucitec, 2016.

38. Rhodes A, Ferdinande P, Flaatten H, Guidet B, Metnitz PG, Moreno RP. The variability of critical care bed numbers in Europe. Intensive Care Medicine. 2012 July; 38(10): 1647-53.

39. Goldwasser RS, Lobo MSC, Arruda EF, Angelo AS, Silva JRL, Salles AA et al . Difficulties in access and estimates of public beds in intensive care units in the state of Rio de Janeiro. Saude Publica. 2016; 50: 19.

40. Caluza ACV, Barbosa AH, Gonçalves I, Oliveira CL, Matos LN, Zeefried C et al. ST-Elevation Myocardial Infarction Network: Systematization in 205 Cases Reduced Clinical Events in the Public Health Care System (Rede de infarto com supradesnivelamento de ST: sistematização em 205 casos diminui eventos clínicos na rede pública). Arq. Bras. Cardiol. 2012; 99(5): 1040-1048.

41. Binsfeld L, Rivera FJU, Artmann E. The process of defining the hospital care profile in federal hospitals in the city of Rio de Janeiro, Brazil (O processo de conformação do perfil assistencial nos hospitais federais da cidade do Rio de Janeiro, Brasil). Cienc. saude coletiva. 2017; 22(1): 209-220.

42. Soares EP, Scherer MDA, O'Dwyer G. Inclusion of a large size hospital in the Urgency and Emergency Network of the Center-West region (Inserção de um hospital de grande porte na Rede de Urgências e Emergências da região Centro-Oeste). Saude debate. 2015; 39(106): 616-626.

43. National Institute for Health and Care Excellence. (2018) Chapter 39. Bed occupancy. In: Emergency and acute medical care in over 16s: service delivery and organisation (NICE Guideline 94). Available at: https://www.nice.org.uk/guidance/ng94/evidence

44. Average length of stay in hospitals. In Health at a Glance 2017: OECD Indicators, OECD Publishing, Paris, 2017.

45. Silva SA, Valácio RA, Botelho FC, Amaral CFS. Reasons for discharge delays in teaching hospitals (Fatores de atraso na alta hospitalar em hospitais de ensino). Rev. Saude Publica. 2014; 48(2): 314-321.

46. Parada R. Building-up the State Health System: antecedents and ways of insertion (A Construção do Sistema Estadual de Saúde: antecedentes e formas de inserção). Physis. 2001; 1(1): 19-104.

\section{Declarations}

Ethics approval and consent to participate

The research obtained Research Ethics Committee approval from two institutions: from the National School of Public Health from Oswaldo Cruz Foundation (Escola Nacional de Saúde Pública Sérgio Arouca - ENSP/FIOCRUZ), approval number CAAE 57132716.0.0000.5240, and from the Municipal Department of Health of Rio de Janeiro (Secretaria Municipal de Saúde do Rio de Janeiro - SMS/RJ), approval number CAAE 57132716.0.3001.5279.

All participants that agreed to participate signed an Informed Consent Form prior to being interviewed.

\section{Consent for publication}

All participants signed an Informed Consent Form that authorized the posterior publication of the results of the research.

\section{Availability of data and materials}

The datasets generated and analyzed during the current study are available in the website of the Health Informatics Department (DATASUS) of Brazilian Ministry of Health.

Health System Indicators were consulted through TABNET, http://tabnet.datasus.gov.br

The four following strings in Portuguese replicate the consult to obtain Health System Indicators:

(a) Procedimentos hospitalares do SUS - por gestor - Rio de Janeiro / Média permanência por Estabelecimento e Ano/mês atendimento / Município gestor:

330455 Rio de Janeiro / Período: Set/2016-Ago/2017.

Page $11 / 18$ 
(b) Procedimentos hospitalares do SUS - por gestor - Rio de Janeiro / Média permanência por Estabelecimento e Ano/mês atendimento / Município gestor: 330455 Rio de Janeiro / Grupo procedimento: 03 Procedimentos clínicos / Subgrupo proced.: 0303 Tratamentos clínicos (outras especialidades), 0304

Tratamento em oncologia, 0305 Tratamento em nefrologia, 0306 Hemoterapia, 0308 Tratamento de lesões, envenenamentos e outros, decorrentes de causas externas, 0309 Terapias especializadas / Período: Set/2016-Ago/2017.

(c) Procedimentos hospitalares do SUS - por gestor - Rio de Janeiro / Internações por Estabelecimento e Ano/mês atendimento / Município gestor: 330455 Rio de Janeiro / Período: Set/2016-Ago/2017.

(d) Procedimentos hospitalares do SUS - por gestor - Rio de Janeiro / Internações por Estabelecimento e Ano/mês atendimento / Município gestor: 330455 Rio de Janeiro / Grupo procedimento: 03 Procedimentos clínicos / Subgrupo proced.: 0303 Tratamentos clínicos (outras especialidades), 0304 Tratamento em oncologia, 0305 Tratamento em nefrologia, 0306 Hemoterapia, 0308 Tratamento de lesões, envenenamentos e outros, decorrentes de causas externas, 0309 Terapias especializadas / Período: Set/2016-Ago/2017.

Health Facilities Information was obtained through the National Health Care Facilities Registry (Cadastro Nacional de Estabelecimentos de Saúde - CNES), http://cnes.saude.gov.br

Additional datasets generated during the current study are available from the corresponding author on reasonable request.

\section{Competing interests}

The authors declare that they have no competing interests

\section{Funding}

Not applicable

\section{Authors' contributions}

MTK made substantial contributions to the conception and design of the study, data collection, analysis and interpretation and wrote the manuscript. GO made substantial contributions to the conception and design of the study, analysis and interpretation of data. All the authors have read and approved the final manuscript.

\section{Acknowledgements}

Not applicable

\section{Tables}


Table 1 - Hospital beds per type, per hospital, per ownership - Rio de Janeiro - 2017

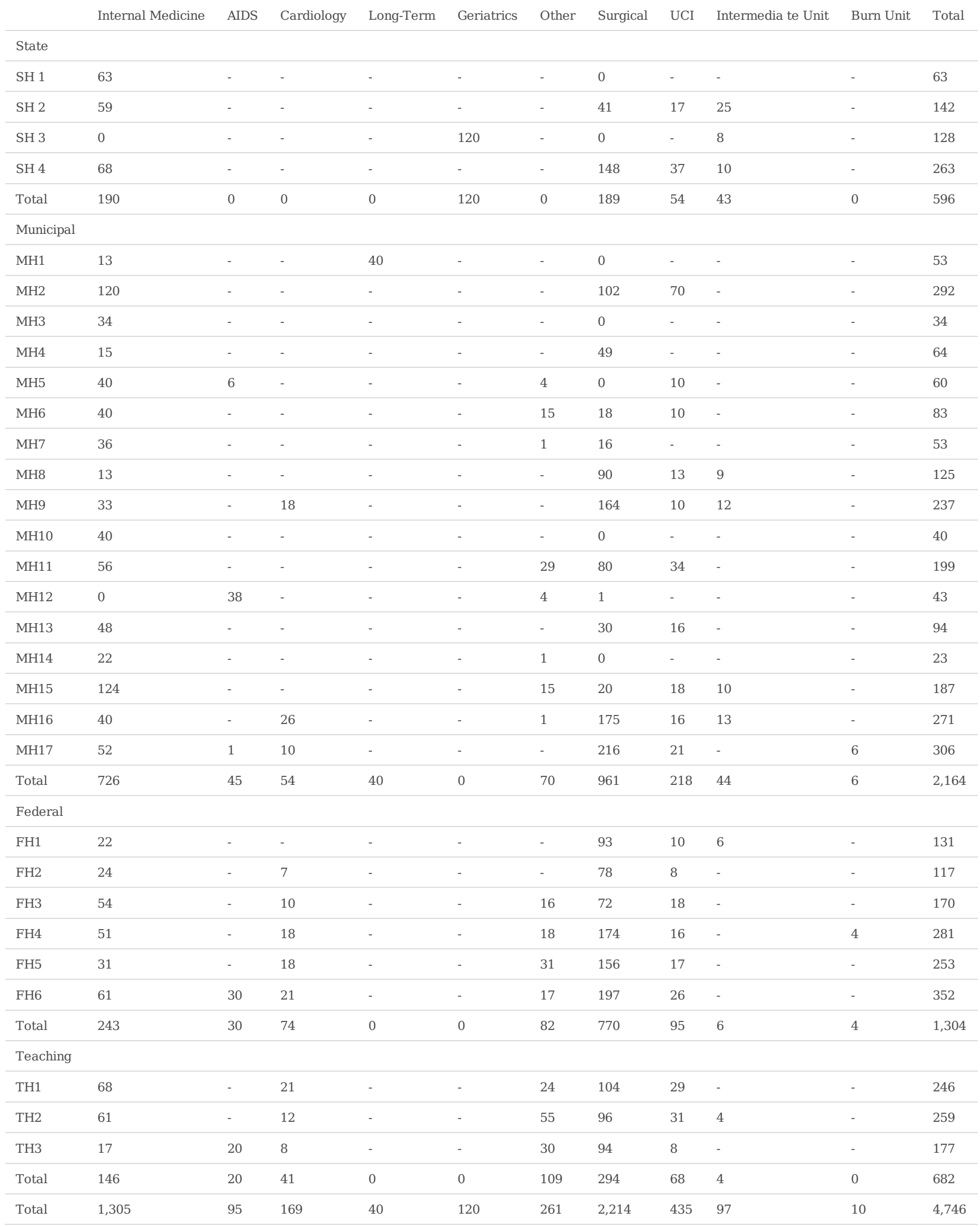

Source: National Health Care Facilities Registry - CNES

Legend: SH: State Hospital; MH: Municipal Hospital; FH: Federal Hospital; TH: Teaching Hospital 
Table 2 - Total number of hospital beds made available to CRMRJ per healthcare facility - Rio de Janeiro/RJ - September2016 to August 2017

\begin{tabular}{|c|c|}
\hline Hospitais & Total \\
\hline MH15 & 2539 \\
\hline MH4 & 480 \\
\hline MH5 & 464 \\
\hline MH10 & 413 \\
\hline MH3 & 403 \\
\hline MH6 & 225 \\
\hline Pre-hospital Unit & 140 \\
\hline MH12 & 188 \\
\hline MH11 & 160 \\
\hline MH9 & 141 \\
\hline $\mathrm{MH} 2$ & 139 \\
\hline MH1 & 109 \\
\hline MH14 & 78 \\
\hline MH17 & 65 \\
\hline MH16 & 37 \\
\hline MH8 & 36 \\
\hline FH3 & 14 \\
\hline Long-term Care Hospital & 13 \\
\hline TH3 & 12 \\
\hline FH4 & 12 \\
\hline Federal Specialized Care Intitute & 9 \\
\hline FH1 & 8 \\
\hline FH6 & 6 \\
\hline FH2 & 3 \\
\hline MH13 & 2 \\
\hline FH5 & 1 \\
\hline Total & 5697 \\
\hline
\end{tabular}

Legend: CER Regional Emergency Centers; MH Municipal Hospital; SH State Hospital; FH Federal Hospital; TH Teaching Hospital 
Table 3 - Selection of hospital beds types and medical technology availability per hospital - Rio de Janeiro/RJ - December 2017

\begin{tabular}{|c|c|c|c|c|c|c|c|c|c|c|c|c|c|c|}
\hline Hospitals & IM Beds & $\begin{array}{l}\text { Surgical } \\
\text { Beds }\end{array}$ & $\begin{array}{l}\text { ICU } \\
\text { Beds }\end{array}$ & $\mathrm{ED}$ & $\begin{array}{l}\text { CT } \\
\text { Scan }\end{array}$ & $\begin{array}{l}\text { MRI } \\
\text { Scan }\end{array}$ & $\begin{array}{l}\text { Ultra } \\
\text { sound }\end{array}$ & Doppler & Echo & Dyalisis & $\begin{array}{l}\text { Endos } \\
\text { copy }\end{array}$ & $\begin{array}{l}\text { Angio } \\
\text { graphy }\end{array}$ & Bronchoscopy & $\mathrm{I}$ \\
\hline \multicolumn{15}{|l|}{ State } \\
\hline SH 1 & 63 & 0 & 0 & - & - & - & $\mathrm{Y}$ & - & - & - & - & - & - & - \\
\hline SH 2 & 59 & 41 & 17 & $\mathrm{Y}$ & $\mathrm{Y}$ & - & $\mathrm{Y}$ & - & $\mathrm{Y}$ & $\mathrm{Y}$ & $\mathrm{Y}$ & - & $\mathrm{Y}$ & - \\
\hline \multirow[t]{2}{*}{ SH 3} & 0 & 0 & 0 & - & - & - & $\mathrm{Y}$ & $\mathrm{Y}$ & - & - & - & - & - & - \\
\hline & 68 & 148 & 37 & $\mathrm{Y}$ & $\mathrm{Y}$ & - & $\mathrm{Y}$ & $\mathrm{Y}$ & $\mathrm{Y}$ & $\mathrm{Y}$ & $\mathrm{Y}$ & - & - & Y \\
\hline
\end{tabular}

$\mathrm{SH} 4$

Municipal

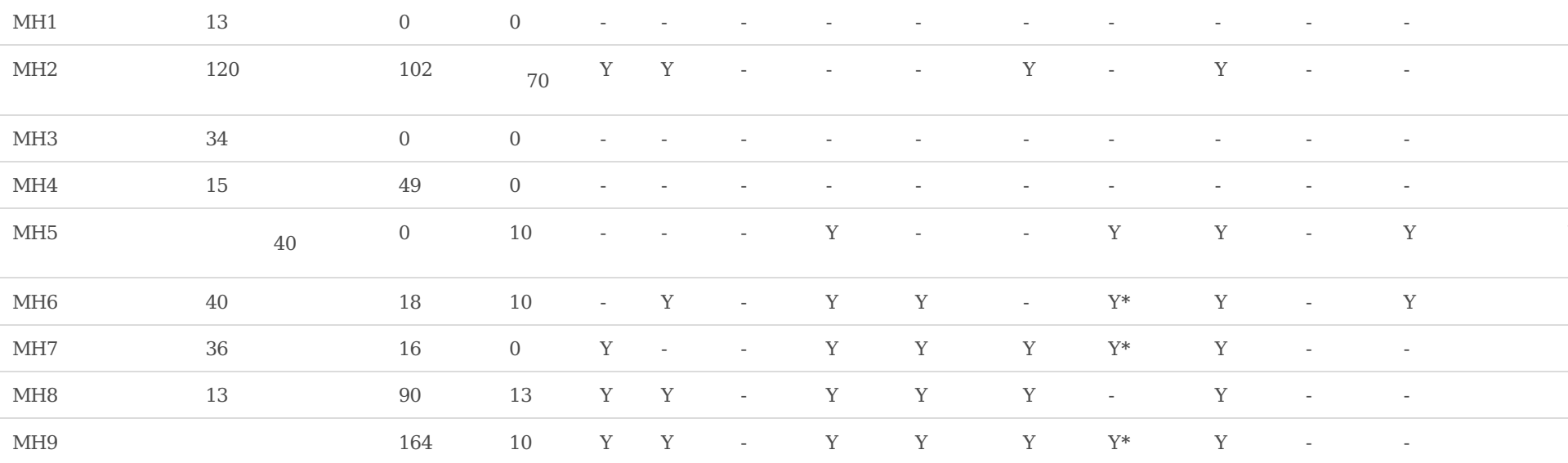

33

\begin{tabular}{|c|c|c|c|c|c|c|c|c|c|c|c|c|c|c|}
\hline MH10 & 40 & 0 & 0 & - & - & - & $\mathrm{Y}$ & $\mathrm{Y}$ & - & - & - & - & - & - \\
\hline MH11 & 56 & 80 & 34 & $\mathrm{Y}$ & $\mathrm{Y}$ & - & $\mathrm{Y}$ & $\mathrm{Y}$ & $\mathrm{Y}$ & $\mathrm{Y}$ & $\mathrm{Y}$ & - & $\mathrm{Y}$ & - \\
\hline MH12 & 0 & 1 & 0 & - & - & - & $\mathrm{Y}$ & $\mathrm{Y}$ & - & - & $\mathrm{Y}$ & - & $\mathrm{Y}$ & - \\
\hline MH13 & 48 & 30 & 16 & $\mathrm{Y}$ & $\mathrm{Y}$ & - & $\mathrm{Y}$ & $\mathrm{Y}$ & $\mathrm{Y}$ & - & $\mathrm{Y}$ & - & - & - \\
\hline MH14 & 22 & 0 & 0 & $\mathrm{Y}$ & - & - & $\mathrm{Y}$ & - & $\mathrm{Y}$ & - & - & - & - & - \\
\hline MH15 & 124 & 20 & 18 & - & - & - & $\mathrm{Y}$ & $\mathrm{Y}$ & $\mathrm{Y}$ & $\mathrm{Y}$ & $\mathrm{Y}$ & - & $\mathrm{Y}$ & - \\
\hline MH16 & 40 & 175 & 16 & $\mathrm{Y}$ & $\mathrm{Y}$ & - & $\mathrm{Y}$ & $\mathrm{Y}$ & $\mathrm{Y}$ & $\mathrm{Y}$ & $\mathrm{Y}$ & - & - & - \\
\hline MH17 & & 216 & 21 & $\mathrm{Y}$ & $\mathrm{Y}$ & - & $\mathrm{Y}$ & $\mathrm{Y}$ & - & $\mathrm{Y}$ & $\mathrm{Y}$ & - & $\mathrm{Y}$ & 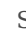 \\
\hline
\end{tabular}

Federal

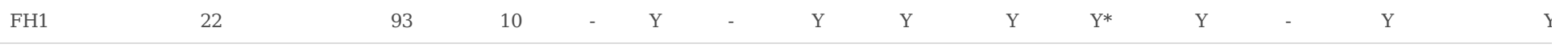




\begin{tabular}{|c|c|c|c|c|c|c|c|c|c|c|c|c|c|c|c|}
\hline FH2 & 24 & & 78 & 8 & $\mathrm{Y}$ & $\mathrm{Y}$ & - & $\mathrm{Y}$ & $\mathrm{Y}$ & $\mathrm{Y}$ & $\mathrm{Y}$ & $\mathrm{Y}$ & - & $\mathrm{Y}$ & Y \\
\hline FH3 & 54 & & 72 & 18 & - & $\mathrm{Y}$ & - & $\mathrm{Y}$ & $\mathrm{Y}$ & $\mathrm{Y}$ & $\mathrm{Y}$ & $\mathrm{Y}$ & $\mathrm{Y}$ & $\mathrm{Y}$ & $Y$ \\
\hline FH4 & 51 & & 174 & 16 & $\mathrm{Y}$ & $\mathrm{Y}$ & - & $\mathrm{Y}$ & $\mathrm{Y}$ & $\mathrm{Y}$ & - & $\mathrm{Y}$ & - & $\mathrm{Y}$ & $Y$ \\
\hline FH5 & & 31 & 156 & 17 & $\mathrm{Y}$ & $\mathrm{Y}$ & - & $\mathrm{Y}$ & $\mathrm{Y}$ & $\mathrm{Y}$ & $\mathrm{Y}$ & $\mathrm{Y}$ & $\mathrm{Y}$ & $\mathrm{Y}$ & $Y$ \\
\hline FH6 & 61 & & 197 & 26 & - & $\mathrm{Y}$ & - & $\mathrm{Y}$ & $\mathrm{Y}$ & $\mathrm{Y}$ & $\mathrm{Y}$ & $\mathrm{Y}$ & $\mathrm{Y}$ & $\mathrm{Y}$ & I \\
\hline \multicolumn{16}{|c|}{ Teaching } \\
\hline TH1 & & 68 & 104 & 29 & - & $\mathrm{Y}$ & $\mathrm{Y}$ & $\mathrm{Y}$ & $\mathrm{Y}$ & $\mathrm{Y}$ & $\mathrm{Y}$ & $\mathrm{Y}$ & $\mathrm{Y}$ & $\mathrm{Y}$ & I \\
\hline TH2 & 61 & & 96 & 31 & $\mathrm{Y}$ & $\mathrm{Y}$ & $\mathrm{Y}$ & $\mathrm{Y}$ & $\mathrm{Y}$ & $\mathrm{Y}$ & $\mathrm{Y}$ & $\mathrm{Y}$ & $\mathrm{Y}$ & $\mathrm{Y}$ & Y \\
\hline TH3 & 17 & & 94 & 8 & - & $\mathrm{Y}$ & - & $\mathrm{Y}$ & $\mathrm{Y}$ & $\mathrm{Y}$ & $\mathrm{Y}$ & $\mathrm{Y}$ & - & $\mathrm{Y}$ & Y \\
\hline
\end{tabular}

Source: National

Health Care

Facilities

Registry - CNES

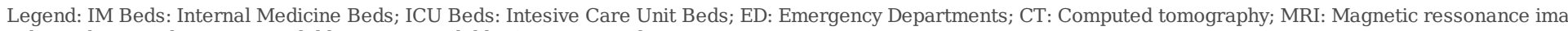
Echocardiogram device; Y: Available; - : Not available, * : outsourced 


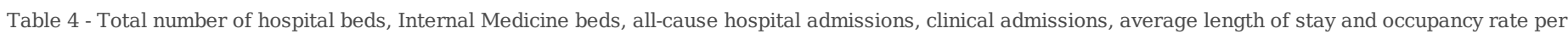
hospital, per ownership - Rio de Janeiro / RJ - September 2016 to August 2017

\begin{tabular}{|c|c|c|c|c|c|c|c|c|}
\hline \multirow[t]{2}{*}{ Hospitals } & \multicolumn{4}{|c|}{ All Bed Types } & \multicolumn{4}{|c|}{ Internal Medicine Beds } \\
\hline & Beds & Adm & LOS & Occ & Beds & Adm & LOS & Occ \\
\hline \multicolumn{9}{|l|}{ State } \\
\hline SH 1 & 63 & 129 & 16.5 & $9 \%$ & 63 & 129 & 16.5 & $9 \%$ \\
\hline SH 2 & 142 & 3006 & 8.25 & $48 \%$ & 59 & 2178 & 9.5 & $96 \%$ \\
\hline SH 3 & 128 & 200 & 39.3 & $17 \%$ & 120 & 200 & 39.3 & $18 \%$ \\
\hline SH 4 & 263 & 9994 & 8.0 & $83 \%$ & 68 & 5681 & 8.6 & $197 \%$ \\
\hline \multicolumn{9}{|l|}{ Municipal } \\
\hline MH1 & 53 & 187 & 38.85 & $38 \%$ & 53 & 185 & 38.85 & $37 \%$ \\
\hline MH3 & 34 & 551 & 26.8 & $119 \%$ & 34 & 551 & 26.8 & $119 \%$ \\
\hline MH4 & 64 & 2015 & 7.35 & $63 \%$ & 15 & 179 & 15.95 & $52 \%$ \\
\hline MH5 & 60 & 5001 & 6.45 & $147 \%$ & 50 & 1277 & 14.5 & $101 \%$ \\
\hline MH6 & 83 & 3683 & 6.1 & $74 \%$ & 55 & 2213 & 7.2 & $79 \%$ \\
\hline MH7 & 53 & 2325 & 6.35 & $76 \%$ & 37 & 757 & 15.2 & $85 \%$ \\
\hline MH8 & 125 & 11717 & 6.75 & $173 \%$ & 13 & 3074 & 9.45 & $612 \%$ \\
\hline MH9 & 237 & 10241 & 9.5 & $112 \%$ & 51 & 2777 & 12.9 & $192 \%$ \\
\hline MH10 & 40 & 409 & 17.6 & $49 \%$ & 40 & 409 & 17.6 & $49 \%$ \\
\hline MH11 & 199 & 12822 & 7.2 & $127 \%$ & 85 & 4481 & 9.75 & $141 \%$ \\
\hline MH13 & 94 & 8996 & 6.45 & $169 \%$ & 48 & 3079 & 10.1 & $177 \%$ \\
\hline MH14 & 23 & 505 & 10.65 & $64 \%$ & 23 & 505 & 10.65 & $64 \%$ \\
\hline MH15 & 187 & 11273 & 6.35 & $105 \%$ & 124 & 3746 & 13.1 & $108 \%$ \\
\hline MH16 & 271 & 9686 & 10.55 & $103 \%$ & 67 & 4216 & 11.8 & $203 \%$ \\
\hline MH17 & 306 & 8715 & 13.6 & $106 \%$ & 63 & 3808 & 13.05 & $216 \%$ \\
\hline \multicolumn{9}{|l|}{ Federal } \\
\hline FH1 & 131 & 5149 & 5.65 & $61 \%$ & 22 & 1130 & 8.95 & $126 \%$ \\
\hline FH2 & 117 & 3897 & 10.2 & $93 \%$ & 31 & 1585 & 15.5 & $217 \%$ \\
\hline FH3 & 170 & 6683 & 6.4 & $69 \%$ & 80 & 1731 & 13.4 & $79 \%$ \\
\hline FH4 & 281 & 5173 & 11.85 & $60 \%$ & 87 & 1999 & 13.15 & $83 \%$ \\
\hline FH5 & 253 & 7841 & 10.1 & $86 \%$ & 80 & 2295 & 16.1 & $127 \%$ \\
\hline FH6 & 352 & 7312 & 7.55 & $43 \%$ & 129 & 2794 & 12.8 & $76 \%$ \\
\hline \multicolumn{9}{|l|}{ Teaching } \\
\hline TH1 & 246 & 5705 & 9.1 & $58 \%$ & 113 & 2410 & 12.5 & $73 \%$ \\
\hline TH2 & 259 & 6750 & 9.15 & $65 \%$ & 128 & 2549 & 14.65 & $80 \%$ \\
\hline TH3 & 177 & 4656 & 5.9 & $43 \%$ & 75 & 1050 & 12.7 & $49 \%$ \\
\hline
\end{tabular}

Source: National Health Care Facilities Registry - CNES and Health Informatics Department - DATASUS

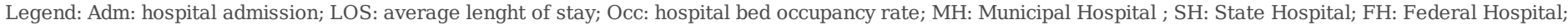
TH: Teaching Hospital 
Table 5 - Internal Medicine and ICU beds made available to CRMRJ per hospital ownership and requesting healthcare facility - Rio de Janeiro/RJ - September 2016 to August 2017

\begin{tabular}{|c|c|c|c|c|c|c|}
\hline Municipal & State & Federal & Teaching & Private & Other & Total \\
\hline Hospital & Hospital & Hospital & Hospital & Hospital & & \\
\hline
\end{tabular}

Internal

Medicine

State UPA

7

7

0

1

$0 \quad 16$

Municipal

329

0

10

1

(1)

$10 \quad 345$

UPA/CER

336

$7 \quad 1$

1

6

$10 \quad 361$

Adult ICU

\begin{tabular}{lccccccc} 
State UPA & 4 & 39 & 2 & 3 & 2 & 0 & 50 \\
$\begin{array}{l}\text { Municipal } \\
\text { UPA/CER }\end{array}$ & 169 & 3 & 2 & 2 & 7 & 2 \\
Total & 173 & 42 & 4 & 5 & 9 & 2 \\
\hline
\end{tabular}

Source: SISREG Database 